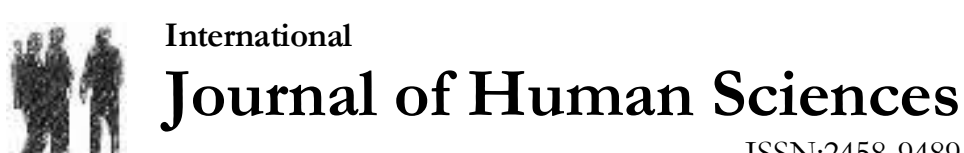 \\ ISSN:2458-9489
}

Volume 15 Issue 2 Year: 2018

\section{The effect of leader-member exchange on job performance of academic staff: An empirical evidence from higher education institutions}

\author{
Mehdi Duyan ${ }^{1}$ \\ Süleyman Murat Yıldız
}

\begin{abstract}
Recently, the relationship between leader-member exchange and job performance has become more interesting subject among researchers. However, the literature has a paucity of empirical studies conducted in the higher education institutions; therefore, the relationship between these two variables is not clear. Hence, the purpose of this study was to examine the effect of leader-member exchange on the job performance of academic staff in higher educational institutions. The data for the study were collected from the academic staff $(n=174)$ of five faculties of sport sciences in Turkey. The LMX-7 scale developed by Scandura and Graen (1984) was used to determine the quality of the interactions between leaders (i.e., administrators) and members (i.e., academic staff). Sigler and Pearson's (2000) job performance scale, which is a modified version of Kirkman and Rosen's (1999) team productivity scale, was used to measure job performance. The findings exposed a statistically significant positive effect of leader-member exchange on job performance $(\mathrm{p}<0.05)$.
\end{abstract}

Keywords: Leader-member exchange; job performance; academic staff; higher education institutions.

\section{Introduction}

During the last few decades, in terms of providing the best educational services, competition among higher educational institutions has increased. Human resources in these institutions have an important role in reaching the best educational service. In this context, academic staff are perceived as one of the most crucial elements in human resources that influence the performance of a higher educational institution and determine its quality (Yildiz, 2016). Teaching, research, and scholarly activities are among the primary tasks of academic staff. Also, these activities are key performance indicators for higher educational institutions (Graham, 2015). Since the performance of the higher education institutions is dependent, primarily, upon the high performance of the academic staff, a variety of studies have conducted recently on what variables affect the performance of academic staff. Job satisfaction (Judge et al., 2001), psychological climate (Biswas \& Varma, 2011), and commitment (Wallace \& De Chernatony, 2009) are examples of these variables. In addition, the quality of the relationship between administrator (i.e., leader) and academic staff (i.e., subordinate) also can affect the performance of academic staff. The phenomenon that explains the quality of relationship is the leader-member exchange (LMX) theory (Winkler, 2010).

\footnotetext{
${ }^{1}$ Lecturer, Bitlis Eren University, School of Physical Education and Sports, duyanmhdi@gmail.com

2 Associate Professor, Muğla Sitk1 Kocman University, Faculty of Sport Sciences, smyildiz@gmail.com
} 
Duyan, M., \& Ylldı, S. M. (2018). The effect of leader-member exchange on job performance of academic staff: An empirical evidence from higher education institutions. Journal of Human Sciences, 15(2), 1129-1136. doi:10.14687/jhs.v15i2.5162

Job performance (JP) is defined as the quantity and quality of the achievement that an individual or a group contributes to the organization (Schermerhorn et al., 2012). Reaching the highest level of both individual and group contributions is a critical factor for the organization as it contributes to achieve the maximum organizational effectiveness and goals. A number of environmental factors (e.g., work relations) affect the JP directly. One of the theories dealing with work relations is LMX theory. This theory focuses on the two-way (dyadic) relationship between the leader and the members of a department or organization, and argues that the interactions between leaders and their subordinates result in a unique relationship, the quality of which influences the performance of both individuals and organizations (Graen \& Schiemann, 1978). Because leaders have limited time, power, and resources in the organization, they cannot use the same leadership style with all subordinates. Therefore, LMX attempts to describe how leaders use their time, power, and resources to develop different relationships with their subordinates (Truckenbrodt, 2000). According to LMX theory, working relations between leader and various groups of subordinates may vary from high-quality to low-quality (Liden \& Graen, 1980). In highquality exchange relationship, leaders establish closer affiliations and give more attention to some subordinates, called the in-group, who they are considered crucial for business operations. Therefore, leaders provide support beyond the expected to these in-group members (Dockery \& Steiner, 1990). Such relationships may lead to several advantages to the subordinates, including positive performance evaluations, career development support (Deluga \& Perry, 1994), ample resources, emotional support (Liden \& Graen, 1980), and trust (Bauer \& Green, 1996). In return, leaders have more loyal and hardworking subordinates (Deluga \& Perry, 1994). By contrast, leaders establish relatively lower-quality relationships with those subordinates, who are not considered within the ingroup. These subordinates are called out-group, and generally, leaders exercise their positional power on them. It can be characterized with low-quality affiliations, less support, lesser interaction, and fewer valued resources (Wilhelm et al., 1993; Yildiz, 2011). In low-quality relationships, leaders expect subordinates to fulfill formal business requirements (Yildiz, 2011). Low-quality relationships may lead to a poor level of JP among the out-group members (Janssen \& Van Yperen, 2004), weaker trust and loyalty (Sanchez \& Byrne, 2004), and low job satisfaction in out-group members (Schriesheim et al., 1998).

Social exchange theory (SET) can be used for the attempt of explaining LMX (Yildiz, 2011). The focus point of SET is on the tangible or intangible exchange between at least two persons. This interpersonal relationship is explained considering reward and cost. According to Blau (1964) who used the term social exchange for the first time, when individuals receive a favor from others they will obligated to repay it in the future. On the other hand, an individual who gives someone a favor will expect the favor to be returned. According to the tenets of SET, individuals can participate in an exchange only if there is an expectation to receive rewards in return for the social costs they incur. Unlike economic exchange, social exchanges do not have specific rules or contracts that govern these relationships, and there is no guarantee that the cost incurred will always be rewarded. An individual's belief in whether the other party will reciprocate is the main determinant in social exchange. Lambe et al. (2001) suggested that a strong belief in reciprocity among individuals is expected to result in greater willingness for exchange. Within the social exchange framework, leaders provide the subordinates in the in-group with greater support beyond the formal job contract, involve them in decisions, offer them organizational resources, and facilitate their access to career development opportunities (Deluga \& Perry, 1991, 1994; Graen \& Uhl-Bien, 1995; Le Blanc et al., 1993). Hence, these supports can increase the motivation of subordinates and subsequent high-quality LMX can lead to increased personal JP. Although there are a few studies in the literature about the relationship between LMX and JP in different service sectors, there are few studies in which the researchers examined the relationship between LMX and $\mathrm{JP}$ in higher educational institutions. Hence, the purpose of the study is to examine and better understand the effect of LMX on JP in the context of higher education. 
Duyan, M., \& Ylldı, S. M. (2018). The effect of leader-member exchange on job performance of academic staff: An empirical evidence from higher education institutions. Journal of Human Sciences, 15(2), 1129-1136. doi:10.14687/jhs.v15i2.5162

\section{Materials and Methods}

\subsection{Measurement Instruments}

Leader-member exchange. In this study, we used a 7-item LMX-7 scale which was developed by Scandura and Graen (1984) to determine the quality of the interactions between leaders (i.e., administrators) and members (i.e., academic staff). The participants responded to each question using a 5-point Likert-type scale ranging from 1 ("extremely ineffective") to 5 ("extremely effective"). Question example include: "How would you characterize your working relationship with your manager?" High-scale values indicated a high quality of LMX.

Job performance. Sigler and Pearson's (2000) JP scale, which is a modified version of Kirkman and Rosen's (1999) team productivity scale, was used to measure JP. The scale consists of six items, and statements were rated on a 7-point Likert-type scale ranging from 1 ("never") to 7 ("always"). Statement examples include: "I meet or exceed my work goals" and "I complete my tasks on time". High-scale values indicated a high JP.

\section{Test for Validity and Reliability}

Confirmatory factor analysis was used in order to confirm the one-dimensional structure of the LMX scale and JP scale. Strong model fit indexes were observed in the confirmatory factor analysis applied to the LMX scale $\left(\chi^{2}=16.9 ; \mathrm{df}=14\right.$; CFI $=.997$; GFI $=.973$; AGFI= .946; RMESA $=$.035). Similarly, good levels of model fit indexes were observed as a result of the confirmatory factor analysis applied to the JP scale $\left(\chi^{2}=4.5 ; \mathrm{df}=9\right.$; CFI $=1.000$; GFI $=.991$; AGFI $=.980$; RMESA $=.000)$. These model fit values met the criteria suggested in the literature (Browne \& Cudeck, 1993; Byrne, 2001). The reliability analysis showed that both scales had high reliability scores $(\alpha=.932$ for the LMX scale; $\alpha=.889$ for the JP scale).

\subsection{Sample Size and Procedure}

The data for this study were collected from the academic staff of five faculties of sport sciences of various state universities in Turkey. First, we got in the touch with the 292 potential academic staff participants via e-mail, including information on the study and an invitation letter. Then, 198 academic staff accepted to participate in the study in a voluntary base, sending back confirmation e-mails. The participants were allowed 2 weeks to complete and return the questionnaires but 177 of them completed questionnaires (89.3\% response rate). After careful inspection, we ignored 3 questionnaires which had missing responses; finally the number of participants was 174 .

\section{Sample Characteristics}

The majority of the sample was males $(75.3 \%)$ and married (68.4\%). Most participants had doctoral degrees $(63.2 \%)$ and were between 26 and 35 years old $(43.7 \%)$. Academic rank of the participants was distributed as follows: lecturer (4.6\%), research assistant (25.3\%), instructor $(33.9 \%)$, assistant professor $(19.5 \%)$, associate professor $(13.8 \%)$, and professor $(2.9 \%)$; and approximately $18 \%$ of them were in the position of administrative. The level of income for most of the participants was between $\$ 1,112$ and $\$ 1,389$ per month. Approximately half of the participants had worked for the same academic institution for less than 10 years (see Table 1). 
Duyan, M., \& Ylldı, S. M. (2018). The effect of leader-member exchange on job performance of academic staff: An empirical evidence from higher education institutions. Journal of Human Sciences, 15(2), 1129-1136. doi:10.14687/jhs.v15i2.5162

Table 1. Sample characteristics

\begin{tabular}{|c|c|c|c|}
\hline Variables & Categories & frequency & $\%$ \\
\hline \multirow{2}{*}{ Gender } & Male & 131 & 75.3 \\
\hline & Female & 43 & 24.7 \\
\hline \multirow{2}{*}{ Marital status } & Married & 119 & 68.4 \\
\hline & Single & 55 & 31.6 \\
\hline \multirow{5}{*}{ Age } & Less than 25 & 2 & 1.1 \\
\hline & $26-35$ & 76 & 43.7 \\
\hline & $36-45$ & 58 & 33.3 \\
\hline & $46-55$ & 28 & 16.1 \\
\hline & More than 56 & 10 & 5.7 \\
\hline \multirow{3}{*}{ Degree } & Undergraduate & 7 & 4.0 \\
\hline & Master & 57 & 32.8 \\
\hline & Doctoral & 110 & 63.2 \\
\hline \multirow{6}{*}{ Title } & Lecturer & 8 & 4.6 \\
\hline & Research Assistant & 44 & 25.3 \\
\hline & Instructor & 59 & 33.9 \\
\hline & Assistant Professor & 34 & 19.5 \\
\hline & Associate Professor & 24 & 13.8 \\
\hline & Professor & 5 & 2.9 \\
\hline \multirow{2}{*}{ Administrative duties } & No & 143 & 82.2 \\
\hline & Yes & 31 & 17.8 \\
\hline \multirow{4}{*}{ Income } & Less than 1111 USD & 5 & 2.9 \\
\hline & 1112-1389 USD & 101 & 58.0 \\
\hline & 1390-1666 USD & 50 & 28.7 \\
\hline & More than 1667 USD & 18 & 10.3 \\
\hline \multirow{6}{*}{$\begin{array}{l}\text { Length of employment } \\
\text { in current institution }\end{array}$} & Less than 5 years & 82 & 47.1 \\
\hline & 6 to 10 years & 41 & 23.6 \\
\hline & 11 to 15 years & 13 & 7.5 \\
\hline & 16 to 20 years & 21 & 12.1 \\
\hline & 21 to 25 years & 14 & 8.0 \\
\hline & More than 26 years & 3 & 1.7 \\
\hline \multirow{6}{*}{$\begin{array}{l}\text { Total length of } \\
\text { working life }\end{array}$} & Less than 5 years & 43 & 24.7 \\
\hline & 6 to 10 years & 50 & 28.7 \\
\hline & 11 to 15 years & 20 & 11.5 \\
\hline & 16 to 20 years & 17 & 9.8 \\
\hline & 21 to 25 years & 31 & 17.8 \\
\hline & More than 26 years & 13 & 7.5 \\
\hline
\end{tabular}

\subsection{Analysis}

Descriptive statistics were given for the basic characteristics of the sample of current study. The confirmatory factor analysis was used to test the unidimensionality of both LMX and JP scales, and Cronbach's Alpha coefficient test was used to check their reliability. Pearson correlation coefficient analysis was conducted using the mean scores of the scale items for each instrument, and the hierarchical regression analysis was used in order to determine the effect of LMX on JP.

\section{Analysis and Results}

\subsection{Correlation Analysis}

Correlation coefficients were computed to include demographic variables, JP, and LMX. Correlation analyses were conducted with the use of mean scores of the scale items for each instrument. Since the scales had high validity and reliability values, averages were used in the analysis to represent each construct. In the literature, information is provided about the low, moderate and high levels of correlation levels among constructs. Cohen (1988) suggested that if the correlation is between 0.1 and 0.3 , it is considered a low correlation, $0.3-0.5$ a moderate correlation, and 0.5-0.7 a high correlation. The result of the correlation analysis in this study showed that there was a significant, positive, and low-level correlation between LMX and JP ( $r=0.193 ; \mathrm{p}<0.05)$. This result indicated that the academic staff will show better JP in case of the increased LMX quality (see Table 2). In addition, there was a significant, positive, and low-level correlation between administrative duties and JP $(\mathrm{r}=0.193 ; \mathrm{p}<0.05)$. 
Duyan, M., \& Ylldı, S. M. (2018). The effect of leader-member exchange on job performance of academic staff: An empirical evidence from higher education institutions. Journal of Human Sciences, 15(2), 1129-1136. doi:10.14687/jhs.v15i2.5162

\begin{tabular}{|c|c|c|c|c|c|c|c|c|c|c|}
\hline Variables & 1 & 2 & 3 & 4 & 5 & 6 & 7 & 8 & 9 & 10 \\
\hline 1. Gender & 1 & & & & & & & & & \\
\hline 2. Marital status & .040 & 1 & & & & & & & & \\
\hline 3. Age & -.132 & $-.390^{* *}$ & 1 & & & & & & & \\
\hline 4. Degree & -.034 & $-.165^{*}$ & .110 & 1 & & & & & & \\
\hline 5. Title & -.148 & $-.373^{* *}$ & $.487^{* *}$ & $.421^{* *}$ & 1 & & & & & \\
\hline 6. Administrative duties & .012 & -.123 & .028 & -.115 & $.196^{* *}$ & 1 & & & & \\
\hline 7. Income & $-.168^{*}$ & $-.183^{*}$ & $.314^{* *}$ & $.283^{* *}$ & $.541^{* *}$ & .096 & 1 & & & \\
\hline $\begin{array}{l}\text { 8. Length of employment in current } \\
\text { institution }\end{array}$ & .003 & $-.363^{* *}$ & $.669^{* *}$ & .072 & $.293^{* *}$ & -.062 & $.182^{*}$ & 1 & & \\
\hline 9. Total length of working life & -.021 & $-.494^{* *}$ & $.861^{* *}$ & $.175^{*}$ & $.522^{* *}$ & .056 & $.316^{* *}$ & $.749^{* *}$ & 1 & \\
\hline 10. LMX & .101 & .050 & $-.262^{* *}$ & $-.292^{* *}$ & -.114 & $.314^{* *}$ & $-.159^{*}$ & $-.301^{* *}$ & $-.252^{* *}$ & 1 \\
\hline 11. JP & .094 & .080 & -.108 & .000 & -.068 & $.193^{*}$ & -.044 & .001 & -.027 & $.193^{*}$ \\
\hline
\end{tabular}

${ }^{*}$ Correlation is significant at the 0.05 level. ${ }^{* *}$ Correlation is significant at the 0.01 level.

\subsection{Hierarchical Regression Analysis}

The results of the hierarchical regression analysis (two steps) showed that JP was positively and significantly affected by $\operatorname{LMX}(\beta=0.182 ; p<0.05)$. On the other hand, for the control variable, JP was affected only by the administrative duties. Accordingly, administrators showed more JP than non-administrators (see Table 3).

Table 3. The results of the hierarchical regression analysis aiming to

\begin{tabular}{|l|c|c|}
\hline \multirow{2}{*}{ identify the relationship between job performance and independent variables } \\
\cline { 2 - 3 } Independent Variables & \multicolumn{2}{|c|}{ Job Performance } \\
\cline { 2 - 3 } 1. Gender & .042 & .028 \\
\hline 2. Marital status & .119 & .133 \\
\hline 3. Age & -.292 & -.268 \\
\hline 4. Degree & .075 & .123 \\
\hline 5. Title & -.125 & -.143 \\
\hline 6. Administrative duties & $.239^{* *}$ & $.193^{*}$ \\
\hline 7. Income & .034 & .046 \\
\hline 8. Length of employment in current institution & .105 & .144 \\
\hline 9. Total length of working life & .233 & .235 \\
\hline 10. LMX & - & $.182^{*}$ \\
\hline F & 1.868 & 2.168 \\
\hline R ${ }^{2}$ & .093 & .117 \\
\hline Adjusted R ${ }^{*}$ & .043 & .063 \\
\hline Note: Standardized beta values were used, ${ }^{* *} p<0.01 ;{ }^{*} p<0.05$ \\
\hline
\end{tabular}

According to the results of the regression analysis, the regression equation related to the estimation of JP is given below:

Job Performance $=(4.092)+(.421 \times$ Administrative Duties $)+(.148 \times$ LMX $)$

\section{Conclusion}

This study presents the results of an empirical study, which was designed to examine the effect of LMX on JP in the higher education context. The quality of LMX had a significant and positive influence on JP, an indication that the incidence of JP was increased, with an increased quality of LMX. Thus, the presence of a significant and positive relationship between these two variables was confirmed for academic staff, as in other fields (Martin et al., 2016; Wang et al., 2008). 
Duyan, M., \& Ylldı, S. M. (2018). The effect of leader-member exchange on job performance of academic staff: An empirical evidence from higher education institutions. Journal of Human Sciences, 15(2), 1129-1136. doi:10.14687/jhs.v15i2.5162

However, an important finding to be emphasized in this study is that LMX has low positive effect on the JP. This finding is similar to those of other studies (Breevaart et al., 2015; Kim et al., 2015; Lin \& Ma, 2004; Luo \& Cheng, 2014). In addition, JP was affected only by the administrative duties as a control variable, namely administrators showed more JP than non-administrator. This may be due to the fact that administrators have more responsibility than non-administrators. Similarly, Biswas and Varma (2011) found that increased job position increased the performance of employees $(r=0.19 ; \mathrm{p}<0.05)$. In contrast to our study results, Siron, Muttar, and Ahmad (2015) investigated the relationship between LMX and JP and found a high correlation between these two variables $(\mathrm{r}=0.66 ; \mathrm{p}<0.01)$. This may be derived from the cultural differences, so further research is a need to examine the relationship between LMX and JP.

In summary, the results of our study exposed that quality of LMX was related to JP. Another interesting point is that the effect of LMX on JP was weak. This may be in consequence of the presence of the rising academic degree status in higher educational institutions. Some of the academic staff may demonstrate teaching and research activities to satisfy their intrinsic motivation, regardless of the quality of their relationship with their leaders. In fact, building positive workplace relationships is vital for career success and the development of good relationships in the workplace increase employee morale. Therefore, administrators should endeavor to increase the quality of LMX to enhance the performance of academic staff. To create high quality of LMX in higher educational institutions, administrators should maximize the number of in-group members. One way to increase the number of in-group members is to involve more academic staff in the decision making process. Furthermore, collegial, civil, and friendly behaviors should be used at all times to cultivate the relationships.

In the higher education context, the studies on the relationship between LMX and JP are quite few. Therefore, for a better understanding of the relationships between these two variables, other researchers should utilize similar research design and analysis methods on the samples from different countries and cultures to prove the results of the present study.

\section{References}

Bauer, T.N. and Green, S.G. (1996). Development of leader-member exchange: A longitudinal test. Academy of Management Journal, 39(6), 1538-1567.

Biswas, S. and Varma, A. (2011). Antecedents of employee performance: An empirical investigation in India. Employee Relations, 34(2), 177-192.

Blau, P.M. (1964). Exchange and power in social life. NY: Wiley.

Bolat, O.I., Bolat, T. and Seymen, O.A. (2009). Investigation of relationship between empowering leader behaviors and organizational citizenship behavior with the reference of social exchange theory. Balikesir University, The Journal of Social Sciences Institute, 12(21), 215-239.

Breevaart, K., Bakker, A.B., Demerouti, E. and Van den Heuvel, M. (2015). Leader-member exchange, work engagement, and job performance. Journal of Managerial Psychology, 30(7), 754-770.

Browne, M.W. and Cudeck, R. (1993). Alternative ways of assessing model fit. In K. A. Bollen \& J. S. Long (Eds.), Testing structural equation models (pp. 136-162). Newbury Park, CA: Sage.

Byrne, B.M. (2001). Structural equation modeling with AMOS - Basic concepts, applications, and programming. Mahwah, NJ: Lawrence Erlbaum Associates.

Cohen, J. (1988). Statistical power analysis for the behavioral sciences. (2nd ed.), NJ: Lawrence Erlbaum.

Deluga, R.J. and Perry, J.T. (1991). The relationship of subordinate upward influencing behaviour, satisfaction and perceived superior effectiveness with leader-member exchanges. Journal of Occupational Psychology, 64(3), 239-252.

Deluga, R.J. and Perry, J.T. (1994). The role of subordinate performance and ingratiation in leadermember exchanges. Group \& Organization Management, 19(1), 67-86. 
Duyan, M., \& Ylldı, S. M. (2018). The effect of leader-member exchange on job performance of academic staff: An empirical evidence from higher education institutions. Journal of Human Sciences, 15(2), 1129-1136. doi:10.14687/jhs.v15i2.5162

Dockery, T.M. and Steiner, D.D. (1990). The role of the initial interaction in leader-member exchange. Group \& Organization Studies, 15(4), 395-413.

Graen, G.B. and Schiemann, W. (1978). Leader-member agreement: A vertical dyad linkage approach. Journal of Applied Psychology, 63(2), 206-212.

Graen, G.B. and Uhl-Bien, M. (1995). Relationship-based approach to leadership: Development of leader-member exchange (LMX) theory of leadership over 25 years: Applying a multi-level multi-domain approach. Leadership Quarterly, 6(2), 219-47.

Graham, A.T. (2015). Academic staff performance and workload in higher education in the UK: The conceptual dichotomy. Journal of Further and Higher Education, 39(5), 665-679.

Greene, W.E., Walls, G.D. and Schrest, L.J. (1994). Internal marketing: The key to external marketing success. Journal of Services Marketing, 8(4), 5-13.

Janssen, O. and Van Yperen, N.W. (2004). Employees' goal orientations, the quality of leadermember exchange, and the outcomes of job performance and job satisfaction. The Academy of Management Journal, 47(3), 368-384.

Judge, T.A., Thoresen, C.J., Bono, J.E. and Patton, G.K. (2001). The job satisfaction-job performance relationship: A qualitative and quantitative review. Psychological Bulletin, 127(3), 376-407.

Kim, T-Y., Liu, Z-Q. and Diefendorff, J.M. (2015). Leader-member exchange and job performance: The effects of taking charge and organizational tenure. Journal of Organizational Behavior, 36(2), 216-231.

Kirkman, B.L. and Rosen, B. (1999). Beyond self-management: Antecedents and consequences of team empowerment. Academy of Management Journal, 42(1), 58-74.

Lambe, C.J., Wittmann, C.M. and Spekman, R.E. (2001). Social exchange theory and research on business-to-business relational exchange. Journal of Business-to-Business Marketing, 8(3), 1-36.

Le Blanc, P.M., Jong, R.D., Geersing, J., Furda, J. and Komproe, I.H. (1993). Leader-member exchanges: Distinction between two factors. European Work and Organizational Psychologist, 3(4), 297-309.

Liden, R.C. and Graen, G. (1980). Generalizability of the vertical dyad linkage model of leadership. The Academy of Management Journal, 23(3), 451-465.

Lin, C-P. and Ma, H.C. (2004). Effects of leader-member exchange, job satisfaction, and organizational commitment on diagnosing employee job performance using career stage as a moderator. Asia Pacific Management Review, 9(1), 79-99.

Luo, B. and Cheng, S.P. (2014). Leader-member exchange, efficacy and job performance: A cognitive perspective interpretation. Canadian Social Science, 10(5), 244-248.

Martin, R., Guillaume, Y., Thomas, G., Lee, A. and Epitropaki, O. (2016). Leader-member exchange (LMX) and performance: A meta-analytic review. Personnel Psychology, 69(1), 67121.

Sanchez, R.J. and Byrne, Z.S. (2004). Leader-member exchange and organizational justice: A new approach. In: New frontiers of leadership, Ed: George B. Graen, Age Publishing, USA.

Scandura, T.A. and Graen, G.B. (1984). Moderating effects of initial leader-member exchange status on the effects of a leadership intervention. Journal of Applied Psychology, 69(3), 428-436.

Schermerhorn, J.R., Osborn, R.N., Uhl-Bien, M. and Hunt, J.G. (2012). Organizational behavior $\left(12^{\text {th }}\right.$ Edition). Hoboken, NJ: John Wiley \& Sons Inc.

Schriesheim, C.A., Neider, L.L. and Scandura, T.A. (1998). Delegation and leader-member exchange: Main effects, moderators, and measurement issues. Academy of Management Journal, 41(3), 298-318.

Sigler, T.H. and Pearson, C.M. (2000). Creating an empowering culture: Examining the relationship between organizational culture and perceptions of empowerment. Journal of Quality Management, 5(1), 27-52. 
Duyan, M., \& Yildı, S. M. (2018). The effect of leader-member exchange on job performance of academic staff: An empirical evidence from higher education institutions. Journal of Human Sciences, 15(2), 1129-1136. doi:10.14687/jhs.v15i2.5162

Siron, R.B., Muttar, A.K. and Ahmad, Z.A. (2015). Leader-member exchange and academic job performance in the Iraqi technical colleges and institutes: The mediating role of job satisfaction. International Review of Management and Business Research, 4(3), 731-742.

Truckenbrodt, Y.B. (2000). The relationship between leader-member exchange and commitment and organizational citizenship behavior. Acquisition Review Quarterly, Summer; 233-244.

Wallace, E. and De Chernatony, L. (2009). Service employee performance: Its components and antecedents. Journal of Relationship Marketing, 8(2), 82-102.

Wang, H., Law, K.S. and Chen, Z.X. (2008). Leader-member exchange, employee performance, and work outcomes: An empirical study in the Chinese context. The International Journal of Human Resource Management, 19(10), 1809-1824.

Wilhelm, C.C., Herd, A.M. and Steiner, D.D. (1993). Attributional conflict between managers and subordinates: An investigation of leader-member exchange effects. Journal of Organizational Behavior, 14(6), 531-544.

Winkler I. (2010). Leader-member exchange theory. In: Contemporary Leadership Theories. Contributions to Management Science. Physica-Verlag HD.

Yildiz, S. M. (2011). Relationship between leader-member exchange and burnout in professional footballers. Journal of Sports Sciences, 29(14), 1493-1502.

Yildiz, S. M. (2016). The effect of internal marketing on organizational citizenship behavior of academic staff in higher educational institutions. Universal Journal of Educational Research, 4(5), $1122-1128$. 